\title{
RHYTHM IN MONOLOGUE VIDEO BY CHARLIE CHAPLIN
}

\author{
Gita Amanda1, Rosi Oktapiani \\ ${ }^{1}$ IKIP Siliwangi \\ ${ }^{2}$ IKIP Siliwangi \\ ${ }^{1}$ gitaamanda77@gmail.com, ${ }^{2}$ rosicimindi@gmail.com
}

\begin{abstract}
The aim of this article is to know about the rhythm of the monologue video by the dialogue of Charlie Chaplin. Rhythm is a characteristic sound that have a strong beat and a weak beat, the writers will try to proof whether it can imitated well or can not imitated well by some of foreign learners. The writers will make a transcript of a dialogue in the last part of the movie The Great Dictator, and as a foreign learner, the writers will try to imitated Charlie Chaplin by watching and listening the character sound that Charlie Chaplin has. The last, the writers will discus the result to find where is the beat that hard to imitated or which the dialogue that hard or easy to imitated. The method of this article is using a qualitative method because this article is about non-numerical language and also focus on analyzing the data.
\end{abstract}

Keywords: Rhythm, Charlie Chaplin, Monologue, The Great Dictator

\section{INTRODUCTION}

Rhythm is a part of phonology, and phonology is a part of linguistic which talk about the sounds of the language that we produce by oral. Rhythm have a characteristic sound that different with general language that we used in daily life, so it is not always can well-imitated by foreign learners. Rhythm have aweak and strong beat in various pattern. The writers take a rhythm on monologue video as an article it is for to know and to give informations for the readers to understand more about rhythm in phonology, so the writers have a lot of question about the rhythm is it such as, what is rhythm?, where is the rhythm can found?, why sometimes the rhythm of sound that produce by mouth have a similar sound? etc.

According to (Brown, 1977) on Discourse Analysis for Language book by Michael McCarthy, she found such recurring patterns in her recording of broadcast talk, actually it can be find in the same way but at a different times.

According to (Scallon, 1982) on Discourse Analysis for Language book by Michael McCarthy, he feel that in spoken interaction, the rhythm a speaker establishes and conforms to represents an underlying tempo (basically the pace or speed of speech, just like the relationship between rhythm and tempo in music), which governs interaction and which gives important clues to participants concerning things such as turn-taking. Other phonologists see a different organising function in rhythm, Taylor (1981) said, in the dividing of information into coherent chunks for the listener.

Monologue, is applied science that teaches about the role arts, and that is only need one person or a mute dialogue to perform sketch scene or in other word, performing the poem or rhyme.

One of the famous advocates in monologue is Charlie Chaplin, he introduce a monologue in hollywood around 1964 and it was developed into a means of art and theatre, and it was become one of the learning theories from the works of theatre. To delivery the monologue that should expressing what is the feels of the person who role a monologue, that is why that person need a good rhythm to expressing the dialogue in poem by monologues. 
One of the most popular monologue in hollywood by Charlie Chaplin is The Great Dictator that was a monochrome movie at 15-10-1940, parody that Chaplin used is not a crude or hilarious parody, but the parody has its own class which elegant. That movie release when world war two Charlie Chaplin as Adolf Hitler walk the way to the top of his glory, and they have successfully parodied that incident.

The writers will analyze The Great Dictator movie video by Charlie Chaplin to know about the rhythm on the monologue that Charlie Chaplin speak is it strong or weak, and is that easy to imitated by the general learners and foreign learners.

\section{METHOD}

The aim of the research method of this article is to get the point target of analyzing the rhythm by monologue video. The participant that the writers used is Charlie Chaplin as the actor who role Adolf Hitler on 'The Great Dictator' movie. The method that the writers used is qualitative method, (Bogdan, 1982) state that qualitative research is descriptive which the data is collected in the form of words or pictures rather than numbers. The data that writers got it is from the video cut by Charlie Chaplin movie, the writers analyze it by herself by watching the video to heard what are Chaplin talk about with the way Chaplin talk and the expression that Chaplin used, and make the transcript from the dialogue that Charlie Chaplin has and the writers will analyzing between theory of rhythm and the transcript of monologue video to get the result of this research is that have a strong beat or weak beat, and is that easy to imitated by the writers.

\section{RESULTS AND DISCUSSION}

\section{Results}

The writers watch a video of Charlie Chaplin and listen carefully to make a transcript of the dialogue in that movie, the writers make a transcript from the best scene of Charlie Chaplin Speech in duration 1:59:10 until 2:02:42 on The Great Dictator movie video. The transcript will be show in the analysis in the discussion down below.

\section{Discussion}

The writers analyze a strong and a weak beat of the transcript that writers have, after that the writers as a foreign learner will try to imitated the sound of Charlie Chaplin in the video. The way to know a strong beat and a weak beat and the transcript dialogue will be list talk by talk :

1. I'm sorry, but I don't want to be an emperor, That not my business

2. I don't want to rule or conquer anyone, I should like to help everyone if possible I I _ _ _ _ _ $I_{-}{ }_{-}{ }_{-}{ }_{-}{ }_{-} I_{-} I_{-}{ }_{-}-$

3. Jew gentile black men white. We all want to help one another. Human beings are like that

4. We want to live by each other's happiness not by each other misery

5. We don't want to hate and despise one another

6. The world has room for everyone and the earth is rich. I can provide for everyone

7. The way of life can be free and beautiful, but we have lost the way 


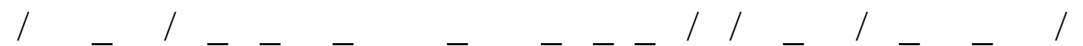

8. Greed has poisoned men's souls, has barricaded the world with hate

9. Has goose stepped us into misery and bloodshed. We have developed speed, / / _ _ _ 1

10. But we have shut ourselves in

$$
\text { / / I _ _ } 1 \text { _ _ _ _ } 1
$$

11. Machinery that gives abundance has left us in want

12. Our knowledge has made us cynical, our cleverness, hard and unkind. We think too much and

feel too little

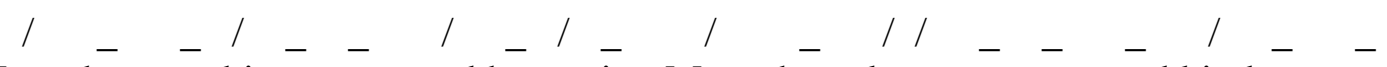

13. More than machinery we need humanity. More than cleverness we need kindness and / I _ gentleness

14. Without these qualities, life will be violent and all will be lost

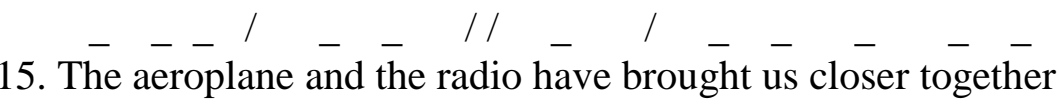

16. The very nature of these inventions cries out for the goodness in men

$$
\text { I } 1 \text { _ } \ldots \ldots 1 / \ldots \ldots
$$

17. Cries out for universal brotherhood for the unity of us all.

$$
1-1-1+1-1 / 1_{-}-1
$$

18. Even now my voice is reaching millions throughout the world

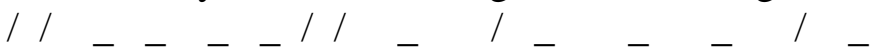

19. Millions of despairing men, woman, and little children
I / _ _ I _ _ I _ $I_{-} I_{-} I_{-} I_{-}{ }_{-}$

20. Victims of a system that makes men tortue and imprison innocent people

21. For those who can hear me I say, do not despair. The misery that is now upon us is but the

passing of greed

22. The bitterness of men who fear the way of human progress

23. The hate of men will pass and dictators die and the power they took from the people

${ }_{-} I_{-} I_{-}{ }_{2} I_{1} I_{-} I_{-} / I_{-} / 1 I_{-}$

24. Will return to the people and so long as men die, liberty will never perish

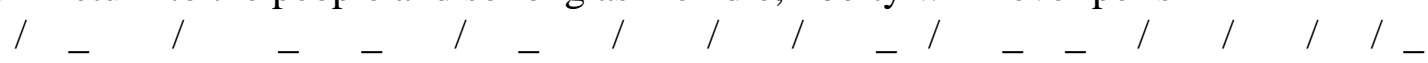

25. Soldiers! Don't give yourselves to brutes, men who despire you, enslave you, who regiment 
your lives

26. Tell you what to do, what to think and what to feel

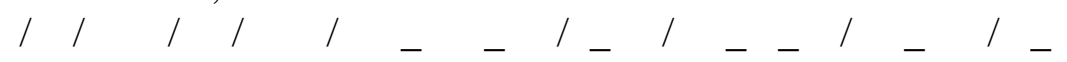

27. Who drill you, diet you, treat you like cattle, use you as cannon fodder

28. Don't give yourselves to these unnatural men, machine men with machine minds and I machine hearts

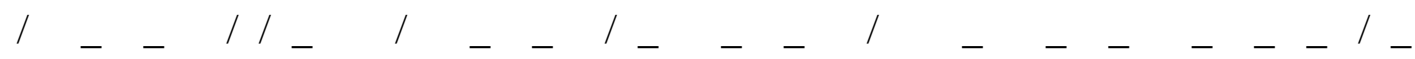

29. You are not machines! You are not cattle! You are men! You have the love of humanity in your hearts!

30. You don't hate! Only the unloved hate the unloved and the unnatural

$$
\text { I _ _ I _ } 1 /{ }_{-} / \text {/ / / }
$$

31. Soldiers! Don't fight for slaverty! Fight for liberty!

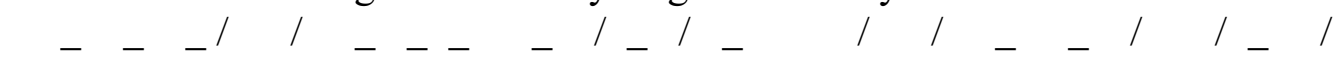

32. In the 17 th Chapter of St Luke it is written : "The kingdom of god within man"

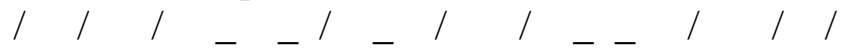

33. Not one man or group of men, but in all men! In you

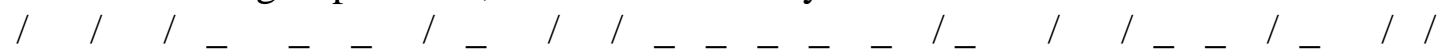

34. You the people have the power, the power to create machines, the power to create happeness

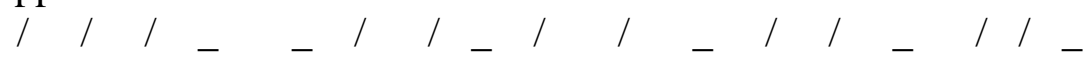

35. You the people, have the power to make this life free and beautiful

1 _ _ _ $-1 / \ldots 1$

to make this life a wonderful adventure

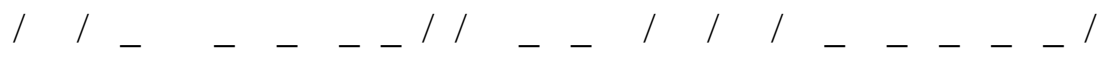

36. Then in the name of democracy, let us use that power, let us all unite.

Let us fight for a new world

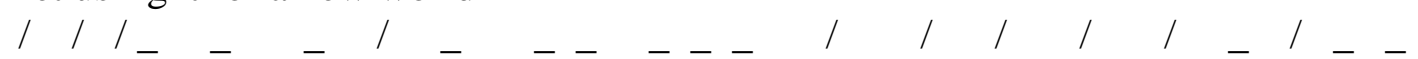

37. A decent world that will give men a chance to work, that will give youth a future and I I _ 1 I_

old age a security

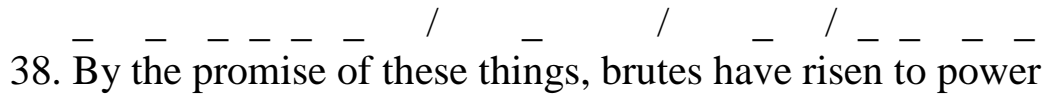

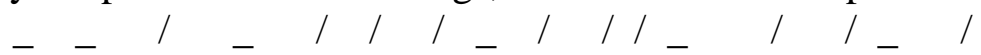

39. But they lie! They do not fulfil that promise. They never will!

40. Dictators free themselves but they ensalve the people!

41. Now let us fight to fulfil that promise. Let us fight to free the world
${ }_{-} I_{-} I_{-} I_{1} /{ }_{-} I_{-}{ }_{-} /$

42. To do away with national barries, to do away with greed

43. With hate and intolerance let us fight for a world of reason

$I_{-} I_{-} I_{-}{ }_{-}{ }_{-} I_{-} I_{-} I_{-}$ 
